Article

\title{
How to Generate Yield in the First \\ Year-A Three-Year Experiment on Miscanthus \\ (Miscanthus $\times$ giganteus (Greef et Deuter)) Establishment under Maize (Zea mays L.)
}

\author{
Moritz von Cossel ${ }^{1, *} *$ (D) Anja Mangold ${ }^{1}$, Yasir Iqbal ${ }^{2, *}$, Jens Hartung ${ }^{3}$, Iris Lewandowski ${ }^{1}$ (i) \\ and Andreas Kiesel ${ }^{1}$ (D) \\ 1 University of Hohenheim, Institute of Crop Science, Biobased Products and Energy Crops (340b), \\ Fruwirthstr. 23, 70599 Stuttgart, Germany; anja.mangold@uni-hohenheim.de (A.M.); \\ iris_lewandowski@uni-hohenheim.de (I.L.); a.kiesel@uni-hohenheim.de (A.K.) \\ 2 College of Bioscience and Biotechnology, Hunan Agricultural University, Changsha, Hunan 410128, China \\ 3 University of Hohenheim, Institute of Crop Science, Biostatistics (340c), Fruwirthstr. 23, \\ 70599 Stuttgart, Germany; moehring@uni-hohenheim.de \\ * Correspondence: moritz.cossel@uni-hohenheim.de (M.v.C.); yasir.iqbal1986@gmail.com (Y.I.); \\ Tel.: +49-711-459-23557 (M.v.C.)
}

Received: 18 April 2019; Accepted: 7 May 2019; Published: 9 May 2019

check for updates

\begin{abstract}
Miscanthus is one of the most promising perennial herbaceous industrial crops worldwide mainly due to its high resource-use efficiency and biomass yield. However, the extent of miscanthus cultivation across Europe is still lagging far behind its real potential. Major limiting factors are high initial costs and low biomass yields in the crop establishment period, especially the first year. This study explores the possibility of establishing miscanthus under maize to generate yields from the first year of cultivation onwards. A field trial with mono-cropped maize and two miscanthus establishment procedures, 'under maize' (MUM) and 'standard' (REF), was established in southwest Germany in 2016. Annual aboveground biomass was harvested in autumn (2016-2018). In 2016 and 2017, the miscanthus dry matter yield (DMY) was significantly lower in MUM than REF. However, the accumulated DMY of miscanthus and maize was as high in MUM as in maize cultivation alone. In 2018, there was no significant difference between the miscanthus DMY of REF $(7.86 \pm 0.77 \mathrm{Mg}$ $\left.\mathrm{ha}^{-1}\right)$ and MUM $\left(6.21 \pm 0.77 \mathrm{Mg} \mathrm{ha}^{-1}\right)$. The accumulated DMY over the three years was $31.7 \mathrm{Mg}$ $\mathrm{ha}^{-1}$ for MUM, of which $10.1 \mathrm{Mg} \mathrm{ha}^{-1}$ were miscanthus-based, compared to $17.7 \mathrm{Mg} \mathrm{ha}^{-1}$ for REF. These results indicate that miscanthus establishment under maize could compensate for its lack of yield in the first year.
\end{abstract}

Keywords: Miscanthus; Maize; Biomass; Biogas; Cropping system; Cultivation; Establishment; Intercropping

\section{Introduction}

Miscanthus $\times$ giganteus (Greef et Deuter) is a high-yielding perennial, rhizomatous C4 grass with a productive lifetime of more than 20 years, if harvested brown after winter [1-5]. As a perennial crop, it requires less fertilizer and herbicide inputs than annual crops [6-8]. A study by McCalmont et al. (2017) [9] showed that perennial crops such as miscanthus can sequester up to $2.2 \mathrm{Mg} \mathrm{ha}^{-1} \mathrm{y}^{-1}$ carbon over a 20-years period. Additionally, miscanthus can be cultivated on marginal lands due to its high resource-use efficiency and tolerance of various abiotic stresses [10-15]. Galatsidas et al. (2018) [11] estimated the total area of marginal land suitable for miscanthus cultivation 
in Europe to be as high as 11.11 million ha. Consequently, miscanthus can be considered a promising industrial crop, both in terms of climate change adaptation and mitigation, and also for the provision of a more environmentally benign biomass supply for a growing bioeconomy [6,15-18].

Miscanthus utilization options include combustion, anaerobic digestion, bioethanol production, building material and animal bedding [1,19-21]. Harvesting times should be adjusted according to utilization pathway chosen. For example, if the biomass is to be used for anaerobic digestion, a green harvest before winter should be performed; for combustion and bioethanol production, a brown harvest after winter is appropriate. This is due to both the increase in lignin and decrease in moisture content, which accompany a delayed harvest [22,23]. A green cut is necessary when using the miscanthus biomass as biogas substrate, since high lignin contents lower its biodegradability, and yield losses over winter reduce the dry matter yield potential by more than $30 \%[23,24]$. A green harvest in October allows for a high methane yield of up to $6000 \mathrm{~m}^{3}$ methane ha ${ }^{-1}[20,23]$.

The miscanthus cultivation area in Europe is however currently only 19,000 ha-quite low compared to other agricultural crops [25]. The main reasons for this are the high establishment costs and the lack of sales markets for the biomass [16,26-30]. Xue et al. (2015) [30] calculated the establishment costs for different propagation methods. They found the cheapest method would be direct seed sowing $\left(1509 € \mathrm{ha}^{-1}\right)$, provided it becomes feasible in future, and the most expensive to be micropropagation $\left(6321 € \mathrm{ha}^{-1}\right)$. The most common procedure, rhizome planting, entails costs of 1904-3375 $€$ [30]. Although future improvements in seed-based establishment could reduce the costs of this method [16,31], it will only be practicable for fertile genotypes. As the most common and commercially available genotype Miscanthus $x$ giganteus is triploid [30], it does not produce fertile seeds. For this reason, clone propagation is performed via rhizomes or plantlets derived from in vitro culture.

Another drawback of the miscanthus production system is the fact that the biomass yield in the first year is too low to make harvesting economically viable and thus no income can be generated [1,26,32]. For this reason, it is usually mulched in early spring instead, as the mulch layer also helps to suppress weed growth. Therefore, miscanthus farmers have high costs for establishment, but no yield and thus, no income to compensate those costs in the first year $[27,29]$. This effect may be intensified (i) in areas with a high land lease, and (ii) on marginal lands with low long-term yield potential [33]. Consequently, there is a need for a miscanthus establishment method that generates yield from the first year of cultivation onwards. One option could be intercropping with a high-yielding 'nurse crop' such as maize (Zea mays L.). This could potentially facilitate the practical large-scale implementation of miscanthus cultivation in the future, because the establishment procedure would entail less economic risk for the farmers. Additionally, the intercropping of miscanthus and maize is expected to have socio-ecological benefits such as soil protection (reduced tillage intensity over time, because maize and miscanthus 'share' soil preparation in the same year), groundwater protection (less herbicide application) and protection of ground-breeding birds (less ground predator activity) [34]. Although miscanthus has been found to be suitable for establishment in grassland systems [35], it remains unclear whether this is also true of establishment under maize or whether the competitive pressure from maize is too high for a successful miscanthus establishment [36].

The aim of this study was to investigate the feasibility of intercropping miscanthus with a second crop during the establishment year. Maize was chosen here as second crop because it has a similar physiology to miscanthus (both C4 grasses), a range of herbicides can be applied to both crops and the miscanthus-maize mix can be ensiled for use as biogas substrate [23]. In addition, maize has been proven to be a suitable intercropping species, for example with legumes [37-41] or perennial wild plant mixtures [42-45]. Biogas production [46] was chosen as the utilization option, as it has recently been found to be a both economically and environmentally promising utilization pathway for miscanthus and other perennial industrial crops $[18,47,48]$. We hypothesized that the establishment of miscanthus under maize would lead to higher accumulated biomass yields over a three-year cultivation period than for the miscanthus mono-cultivation reference. 


\section{Materials and Methods}

\subsection{Weather Conditions and Soil Characteristics}

A field trial was conducted on a site near the University of Hohenheim in southwest Germany $\left(48^{\circ} 42^{\prime} 56.9^{\prime \prime} \mathrm{N}, 9^{\circ} 12^{\prime} 53.2^{\prime \prime} \mathrm{E}, 407 \mathrm{~m}\right.$ above sea level). The overall weather conditions during the field trial are presented in Figure 1. Some specific weather observations worthy of mention are: (i) in winter 2016-2017, the lowest soil temperature ( $5 \mathrm{~cm}$ depth) was only $-1.84{ }^{\circ} \mathrm{C}$, (ii) in summer 2018 , drought conditions prevailed from mid-April to mid-May and from mid-June to the end of August, and (iii) negative climatic water balances (precipitation minus potential evaporation) were recorded in $2016\left(-107.9 \mathrm{~mm} \mathrm{a}^{-1}\right)$ and $2018\left(-159.1 \mathrm{~mm} \mathrm{a}^{-1}\right)$. The annual precipitation was $595.4 \mathrm{~mm}(2016)$, $830.9 \mathrm{~mm}$ (2017) and $649.7 \mathrm{~mm}$ (2018). The soil is characterized by clayey loam (Luvisol). The topsoil $\mathrm{pH}$ averaged 6.3 in spring 2014. Therefore, $1.5 \mathrm{Mg}$ quicklime $(77 \% \mathrm{CaO}) \mathrm{ha}^{-1}$ were applied in spring 2014. In March 2015, the following amounts of macronutrients were applied: $88 \mathrm{~kg}$ phosphorous $\mathrm{ha}^{-1}, 176 \mathrm{~kg}$ potassium ha ${ }^{-1}, 32 \mathrm{~kg}$ magnesium ha ${ }^{-1}, 48 \mathrm{~kg}$ sulphur ha ${ }^{-1}$.

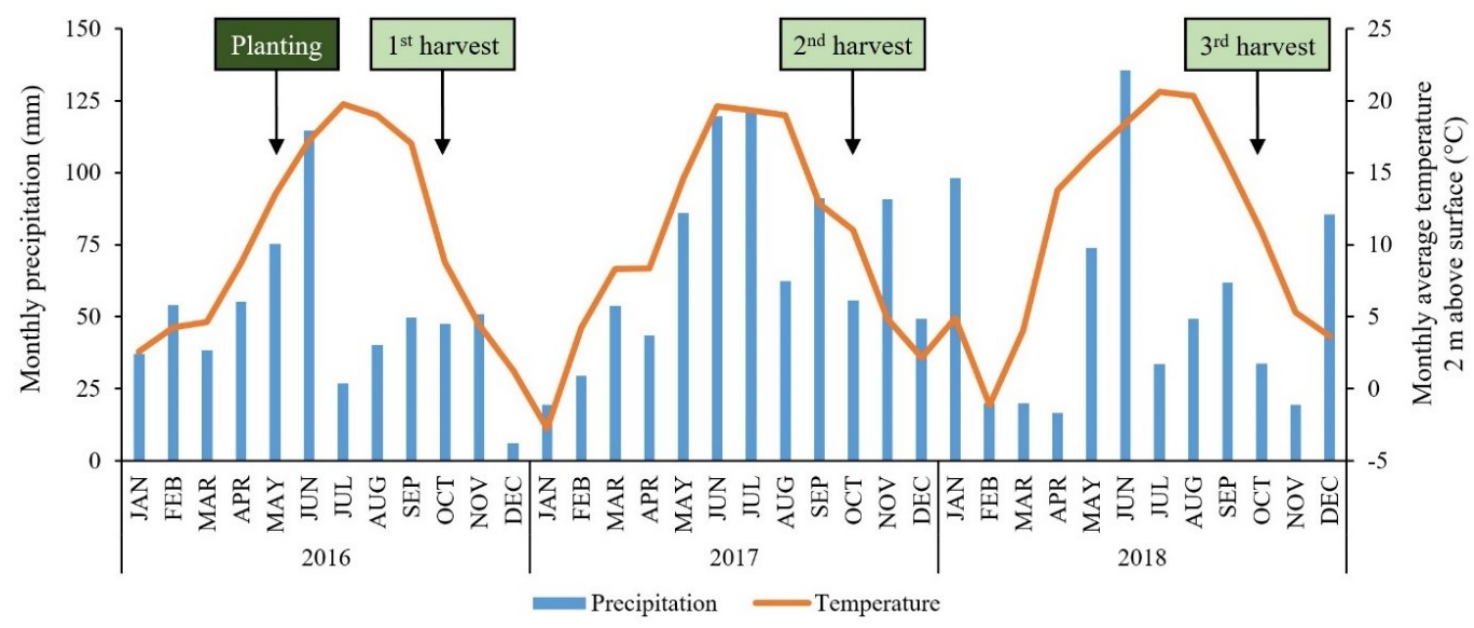

Figure 1. Monthly precipitation totals (bars) and average monthly air temperatures $2 \mathrm{~m}$ above surface (line) at field trial site (Hohenheim, southwest Germany) during cultivation period 2011-2015 (data provided by LTZ Augustenberg, Karlsruhe, Germany). Key agronomic measures (planting and harvest dates) are also indicated.

The plots with miscanthus under maize (MUM), miscanthus as control (REF) and mono-cropped maize (mono-maize) presented in this study were integrated into an existing field trial in 2016. The existing field trial was initiated in 2014 and contained 15 treatments allocated to plots in a completely randomized design with 2 to 5 replicates. Plots of $36 \mathrm{~m}^{2}$ were arranged in six rows, each with nine plots. Of these 54 plots, eight were used for the current study: five plots were originally cultivated with monocropped maize and three plots with monocropped amaranth (Amaranthus hypochondriacus L.). Two of the five maize plots were randomly selected to be used as maize reference in 2016. The remaining six plots were used for the miscanthus establishment treatments (MUM and REF); the three replicates of each were randomized taking the previous crop into account.

\subsection{Miscanthus Planting Procedures and Maize Sowing}

Miscanthus was either established under maize (MUM) (Figure 2a) or on its own (REF). Both treatments used pre-grown (greenhouse) plantlets (Figure $2 b$ ) with a relatively uniform plant height of approx. $30 \mathrm{~cm}$. Prior to planting, the leaves of the largest plantlets were trimmed (Figure $2 \mathrm{~b}$ ) to reduce drought stress. After planting, all plantlets were irrigated manually. In total, $2 \mathrm{~m}^{3}$ water (equivalent to $9.3 \mathrm{~mm}$ irrigation or $9.52 \mathrm{l} \mathrm{plant}^{-1}$ ) were applied to the six miscanthus plots together during the first week after planting (Figure $2 a, b$ ). 

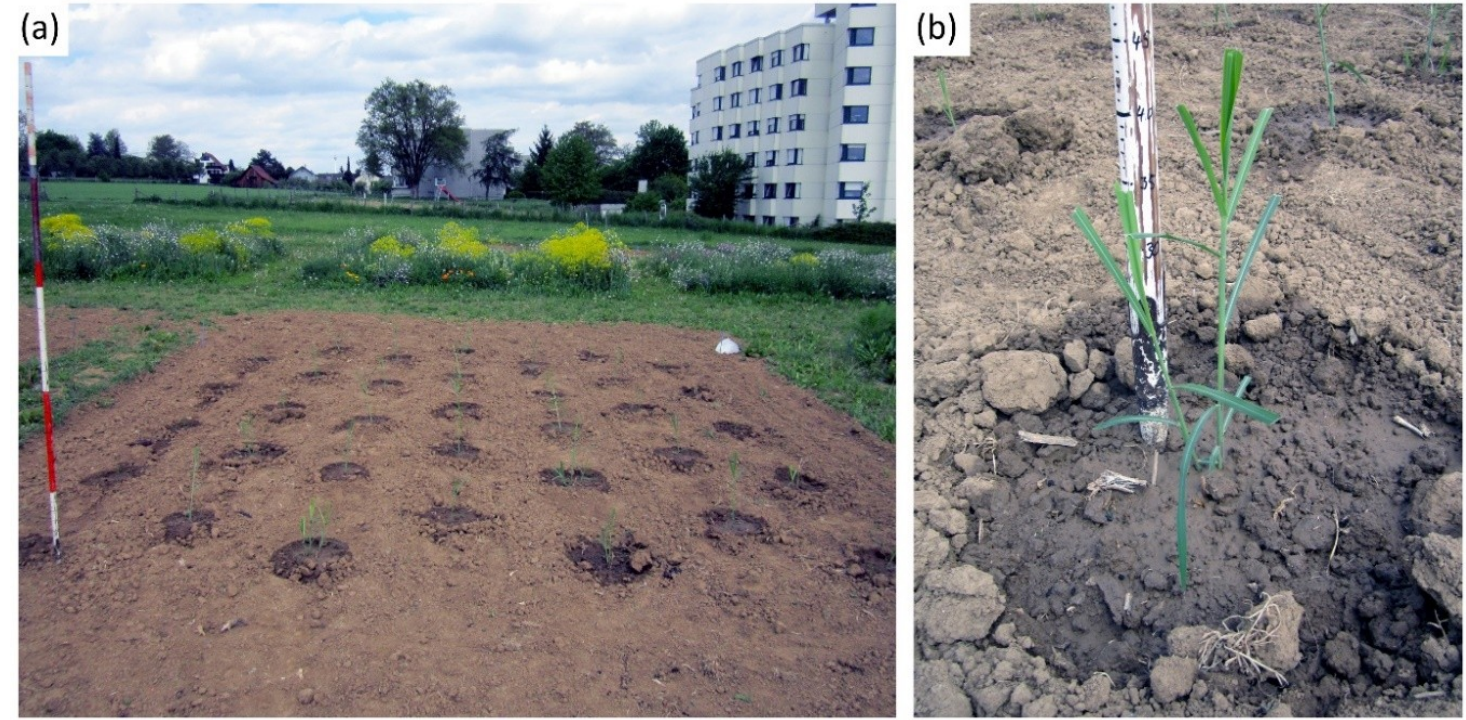

Figure 2. A manually irrigated miscanthus under maize plot one day after planting on 18.5.2016 (a) and a close-up of a representative miscanthus plantlet showing the intensity of leaf trimming (b). In both (a) and (b), the rows with maize sown are recognizable.

The planting geometry of REF and MUM was similar as described in the following text: both, planting density and row distances (within and between the rows) of miscanthus were oriented in the center of the inter-row of commonly sown silage maize in MUM ( 9 kernels $\mathrm{m}^{-2}, 75 \mathrm{~cm}$ row distance). Thus, miscanthus was planted with $75 \mathrm{~cm}$ row distance (Figures 3 and A1). The distance between miscanthus plantlets within the rows was adjusted accordingly $(120 \mathrm{~cm})$ to provide a planting density of 1.1 plants $\mathrm{m}^{-2}$. An offset of $0.4 \mathrm{~m}$ was arranged between the plants in side-by-side miscanthus rows (Figure 3) both to optimize area exploitation and to reduce growth competition between the miscanthus plants. This resulted in seven rows per plot each including five miscanthus plantlets (Figures 2a and 3). In MUM, these seven rows were inter-sown by eight rows of silage maize. For both REF and MUM, only nine plants of the inner core of the plot were considered for harvest to avoid boundary effects.

(a)

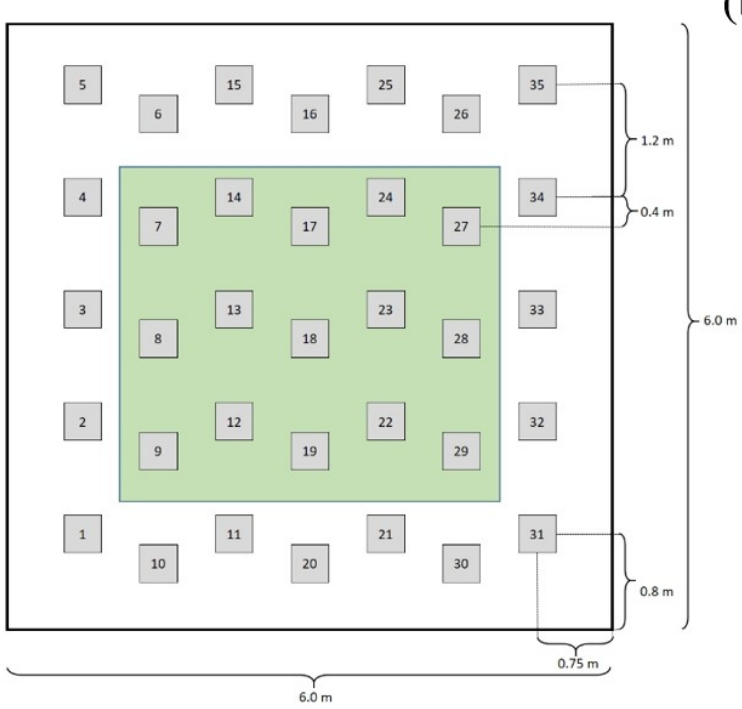

(b)

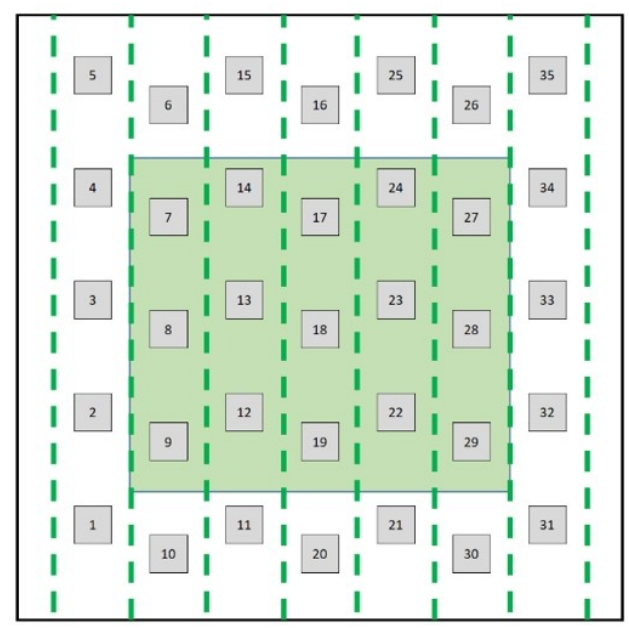

Figure 3. Overview of the planting geometry from the two miscanthus establishment treatments: (a) single establishment (REF), and (b) under maize (MUM). The numbers represent the arrangement of the 35 miscanthus plants per plot. The green box emphasizes all miscanthus plants belonging to the inner core of each plot in both treatments. The dotted green lines in $(\mathbf{b})$ indicate the rows of maize sown. 
For both maize treatments, mono-cropping (mono-maize) and MUM (in 2016 only), the variety Mikado (Zea mays L. cv Mikado, KWS Saat SE, Germany), a variety commonly used as biogas substrate, was sown with 9.5 kernels $\mathrm{m}^{-2}$ and a row distance of $75 \mathrm{~cm}$, using a single seed planter. For MUM, maize was sown before miscanthus was planted. In 2018, maize was cultivated on another field trial next to the field trial described above. Therefore, the results of mono-maize from the year 2018 were not considered for the statistical analyses. Only in 2016, the results of mono-maize were used for statistical analysis.

All treatments including maize (mono-maize and MUM) were fertilized with $90 \mathrm{~kg} \mathrm{~N}$ (via ENTEC ${ }^{\circledR} 26 \mathrm{~N}, \mathrm{BASF}$ ) one day before sowing of maize (16.05.2016). On the same day, REF received $50 \mathrm{~kg} \mathrm{~N} \mathrm{ha}^{-1}$. One month after the establishment procedures, herbicides were applied as follows: 1,137.5 $\mathrm{g} \mathrm{ha}^{-1}$ Pendimethalin (as $2.51 \mathrm{ha}^{-1}$ Stomp Aqua ${ }^{\circledR}$, BASF Ludwigshafen, Germany) in combination with $50 \mathrm{~g} \mathrm{ha}^{-1}$ Tritosulfuron $+100 \mathrm{~g} \mathrm{ha}^{-1}$ Dicamba (as $0.2 \mathrm{~g} \mathrm{ha}^{-1}$ Arrat ${ }^{\circledR}$, BASF Ludwigshafen, Germany) and $345 \mathrm{~g} \mathrm{ha}^{-1}$ fatty acid methyl ester $+205 \mathrm{~g} \mathrm{ha}^{-1}$ fatty alcohol alkoxylates $+46 \mathrm{~g} \mathrm{ha}^{-1}$ oleic acid (as $11 \mathrm{ha}^{-1}$ Dash $^{\circledR}$, BASF Ludwigshafen, Germany). In subsequent years, mechanical weeding was conducted in July in all plots. From 2017 onwards, all treatments including miscanthus (MUM and REF) were fertilized with $50 \mathrm{~kg} \mathrm{~N} \mathrm{ha}^{-1} \mathrm{y}^{-1}$, whereas mono-maize received $90 \mathrm{~kg} \mathrm{~N} \mathrm{ha}^{-1} \mathrm{y}^{-1}$.

\subsection{Harvest Management}

Each plot with a miscanthus treatment (MUM, REF) was harvested each year in autumn. The sampling area covered nine plants per plot. For autumn harvest in 2016 (13th October), the optimal maturity stage of maize for whole crop silage (BBCH 77: lactic ripeness) was used to identify the harvesting time. In 2017 and 2018, the autumn harvest for miscanthus was also conducted in mid-October (18th and 10th October, respectively). This was chosen because mid-October is the recommended harvesting time for miscanthus utilization through anaerobic digestion [20,49].

At each harvest, both the average height and number of shoots per (miscanthus) plantlet were measured. Then they were cut by hand at a cutting height of about $10 \mathrm{~cm}$. After that, the fresh matter yield (FMY) of nine plants of the core of the plots (Figure 2a) was determined. For 10 randomly chosen representative shoots of these plants, the dry matter content of the fresh biomass (DMC) was analyzed. In years 2016 to 2018, mono-maize was harvested by hand on $1.5 \mathrm{~m}^{2}$ per plot. In 2016, this was also conducted for maize in MUM. Based on FMY and DMC, the dry matter yield (DMY) of both maize and miscanthus was calculated.

\subsection{Statistical Analyses}

Data were analyzed using a mixed model approach. Depending on the trait, either plots with maize or plots with miscanthus were considered in the analysis. In both cases the model was as follows:

$$
y_{i j k}=\mu+b_{k}+(b \varphi)_{j k}+\tau_{i}+\varphi_{j}+(\tau \varphi)_{i j}+e_{i j k}
$$

where $\mu$ is the intercept and $b_{k}$ and $(b \varphi)_{j k}$ are the fixed across year and year-specific effect of the $\mathrm{k}^{\text {th }}$ the pre-treatment. $\tau_{i}, \varphi_{j}$, and $(\tau \varphi)_{i j}$ are the fixed effects for the $\mathrm{i}^{\text {th }}$ establishment method, the $\mathrm{j}^{\text {th }}$ year and their interaction effects, respectively. $e_{i j k}$ is the error of observation $y_{i j k}$ with propagation method specific variance. Note that two establishment methods are used in the analysis of all traits. For data measured from miscanthus these are REF and MUM, for data measured in maize these are maize in MUM and mono-cropped maize (mono-maize). As repeated measures were taken from each plot across years, different error variance structures (compound symmetry, first order autoregressive both with homogeneous and heterogeneous variances as well as unstructured) were fitted to account for temporal correlation. The best model was selected via the Akaike information criterion (AIC) [50]. The assumptions of normality and homogeneous error variance were checked graphically. If required, a logarithmic transformation was used to reach assumptions. The influence of factors was tested via a 
global $\mathrm{F}$ test. If differences were found, a multiple $\mathrm{t}$-test was performed to create a letter display [51]. All analysis run using the PROC MIXED procedure of the SAS ${ }^{\circledR}$ Proprietary Software 9.4 TS level 1M5 (SAS Institute Inc., Cary, NC, USA). Both degrees of freedom and standard errors were approximated using the Kenward-Roger method [52].

\section{Results}

\subsection{Dry Matter Yield and Dry Matter Content of Maize}

In 2016, there was no significant difference of maize dry matter yield (DMY) between MUM $\left(21.64 \pm 1.7 \mathrm{Mg} \mathrm{ha}^{-1}\right)$ and mono-maize $\left(19.83 \pm 1.7 \mathrm{Mg} \mathrm{ha}^{-1}\right)$. The dry matter content (DMC) of maize also did not differ significantly between MUM (34.5\%) and mono-maize (35.6\%). The estimated average annual DMY of mono-maize over the three years of observation accounted for $22.4 \pm 2.1 \mathrm{Mg} \mathrm{ha}^{-1}$ with an estimated average DMC of $33.3 \pm 2.2 \%$.

\subsection{Dry Matter Yield and Dry Matter Content of Miscanthus}

For autumn harvest, dry matter yield (DMY) of miscanthus in both, MUM and REF, increased from 2016 to 2018 (Figure 4). In years 2016 and 2017, the miscanthus biomass DMY of MUM was significantly lower than REF (Figure 4). However, the yield of MUM in 2017 (first standalone year of miscanthus within MUM) was three times higher than the yield of REF in its first year (2016). In year 2018, there was no significant difference between the DMY of REF $\left(7.86 \pm 0.77 \mathrm{Mg} \mathrm{ha}^{-1}\right)$ and MUM $\left(6.21 \pm 0.77 \mathrm{Mg} \mathrm{ha}^{-1}\right)$. The DMC was similar between the both variants ranging from $32.3 \%$ (REF in year 2016) to $49.7 \%$ (REF in year 2018) (Figure 4).

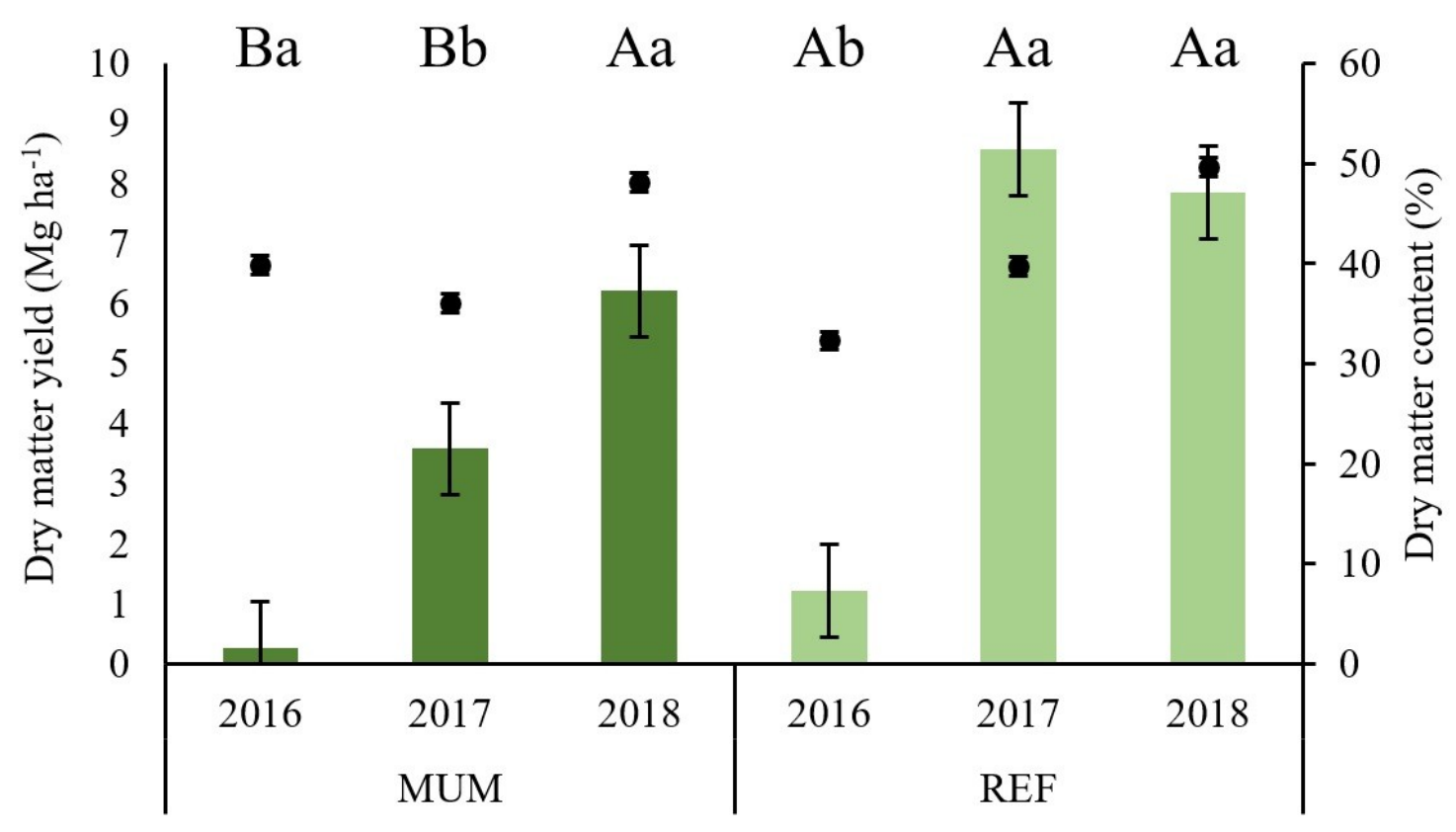

- Dry matter yield $\bullet$ Dry matter content

Figure 4. Dry matter yield (DMY) and dry matter content (DMC) of miscanthus cultivated alone (REF) and under maize (MUM). DMY is shown by bars, DMC by dots. The error bars show the standard errors. Different letters indicate significant $(p<0.05)$ differences between the treatments (MUM and $\mathrm{REF}$ ) within years. Upper case letters refer to the dry matter yield and lower-case letters to the dry matter content. 


\subsection{Accumulated Per Hectare Yield over Three Years}

Figure 5 gives an overview over the accumulated DMY from the three systems REF, MUM and maize-monoculture over the three considered years (2016-2018). MUM had a DMY of $31.7 \mathrm{Mg} \mathrm{ha}^{-1}$, from which $10.1 \mathrm{Mg} \mathrm{ha}^{-1}$ stem from miscanthus (=33.7\% of total harvested biomass). REF had a yield of $17.6 \mathrm{Mg} \mathrm{ha}^{-1}$ over the three years, which is less than the total harvested biomass of MUM, but more than the miscanthus biomass in MUM. Mono-cropped maize reached the highest accumulated yield (67.2 $\mathrm{Mg} \mathrm{ha}^{-1}$ ) of all three systems (Figure 5). However, the DMY of maize in 2018 was not used for statistical analysis but was still comparable in terms of soil and management practices.

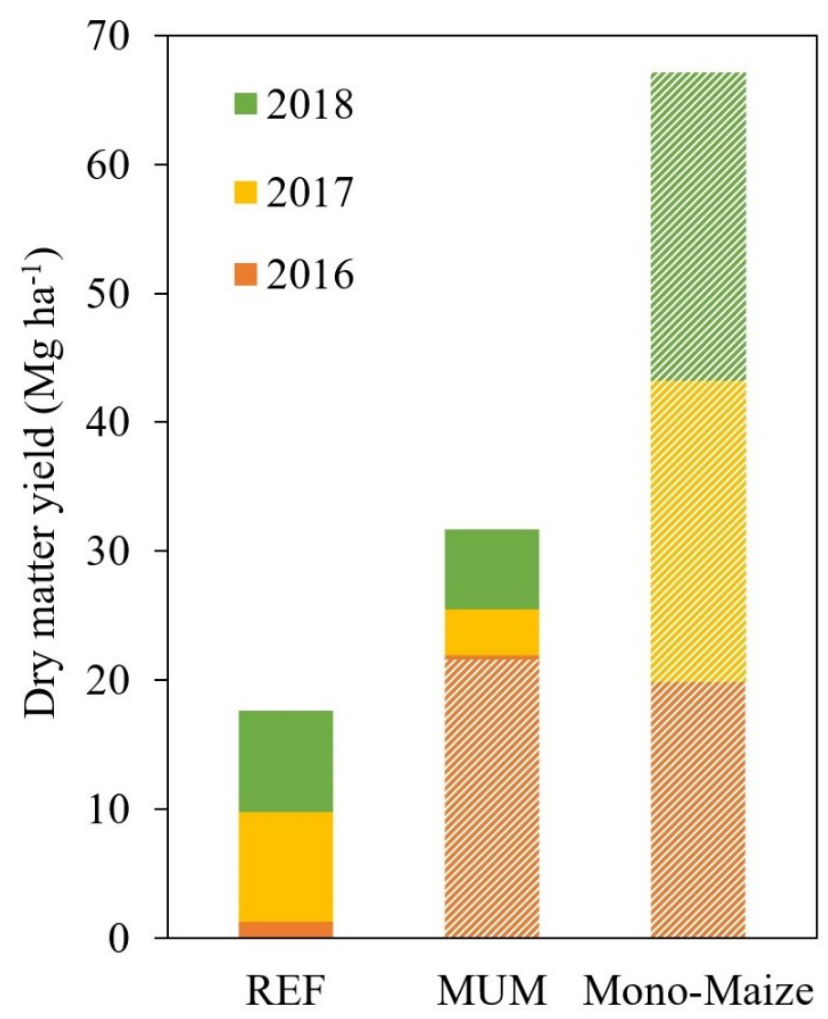

Figure 5. Accumulated dry matter yields (DMY) of single establishment of miscanthus reference (REF), miscanthus under maize (MUM) and mono-cropped maize (Mono-Maize) over three years (2016 to 2018). Each year, the crops were harvested in autumn (green harvest for biogas production). For MUM, maize and miscanthus were harvested and analyzed separately in 2016. Maize DMYs are shaded. Maize DMY in 2018 was taken from another field trial nearby the field trial of this study due to technical reasons.

\subsection{Plant Performance of Miscanthus}

As shown in Figure 6, the miscanthus plants of REF (Figure 6a) resprouted much earlier and with a higher number of shoots than MUM (Figure 6b) in spring 2017. Moreover, the REF (Figure 6d) had a higher stand density than MUM (Figure 6c) in the third year after planting. Concerning weed pressure, high presence of dandelion (Taraxacum officinale F.H. Wigg.) and creeping thistle (Cirsium arvense L. Scop.) and other weeds were observed in MUM in spring 2017. Therefore, mechanical weeding was conducted. In October 2018, the weed species were harvested species-specifically by hand. Their above surface DMY accounted for $0.55 \mathrm{Mg} \mathrm{ha}^{-1}$ in MUM and $0.09 \mathrm{Mg} \mathrm{ha}^{-1}$ in REF (Table A1). 

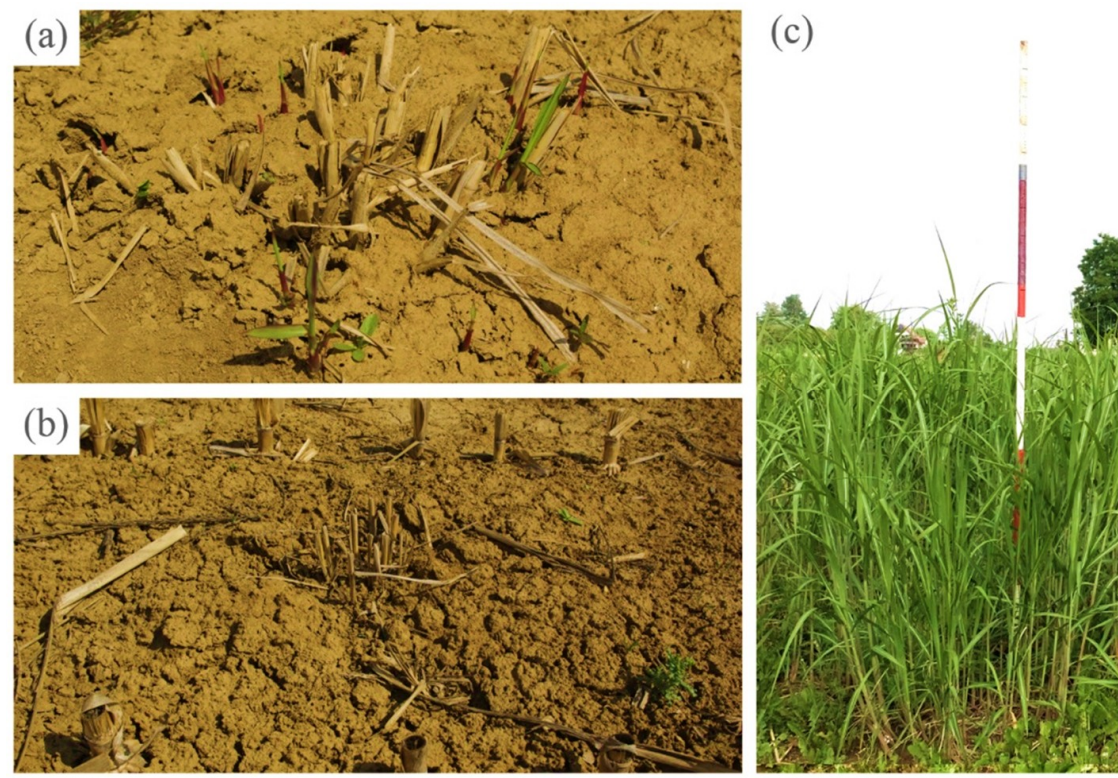

(d)

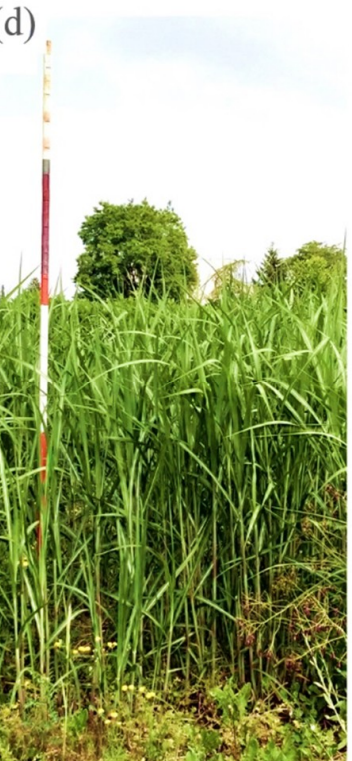

Figure 6. Resprouting of miscanthus cultivated solely (REF) (a) and under maize (MUM) (b) in April 2017. Pictures $(\mathbf{c}+\mathbf{d})$ show the plant stands of MUM (c) and REF $(\mathbf{d})$ in June 2018.

Figure 7 shows the number and dry matter weight of shoots for REF and MUM in the years 2016-2018. In each year, REF had higher shoot numbers than MUM. The average number of shoots in the years 2016 to 2018 of REF (average: 28.8) was twice as high compared to MUM (average: 14.6) (see Figure 7). The shoot dry matter weight was (significantly) higher for REF compared to MUM in year 2016, in year 2018 it was vice versa (significant) and in year 2017 there was no difference. The average shoot dry matter weight over the three years was for REF $17.6 \mathrm{~g}$ and for MUM $19.1 \mathrm{~g}$. 


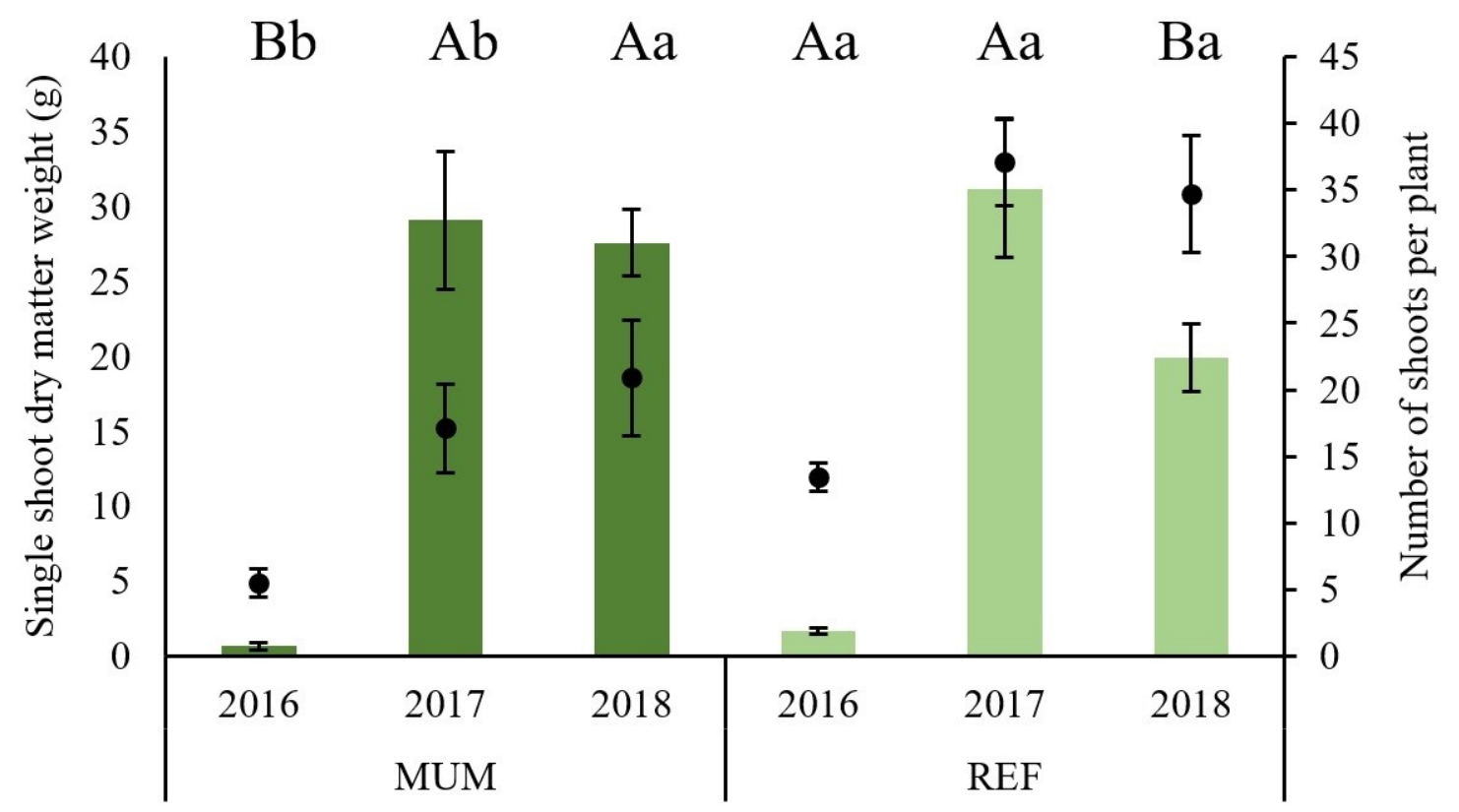

- Single shoot dry matter weight $\quad$ Number of shoots per plant

Figure 7. Number of shoots and single shoot dry matter weight (g) of miscanthus cultivated solely (REF) and under maize (MUM). Shoot dry matter weight is shown by bars, number of shoots by dots. The error bars show the standard deviations. Different letters indicate significant $(p<0.05)$ differences between the treatments (MUM and REF) within years, whereas upper case letters refer to shoot dry matter weight and lower-case letters to the number of shoots per plant.

\section{Discussion}

This study revealed that an establishment of miscanthus under maize is possible and can increase the accumulated three-year dry matter yield compared to sole establishment. Against this, MUM still yielded considerably lower than mono-cropped maize over a period of 3 years (Figure 5). In this context, it must be recognized that during this 3-year period miscanthus may not yet have reached peak yield [16]. In the longer term, miscanthus may therefore compete better with mono-cropped maize. Also, the trial has been performed on a rather fertile soil on which miscanthus is less competitive with maize than under marginal conditions $[23,53]$. However, the comparison of miscanthus cultivation and mono-cropped maize was not considered in this study. Instead, we want to discuss i) the first findings on the establishment of miscanthus under maize of this study, and ii) the required technical adaptations for improving this novel miscanthus establishment procedure.

\subsection{First Findings on Establishing Miscanthus under Maize}

As shown in the results section, MUM resulted in a higher accumulated DMY of maize and miscanthus for the years 2016-2018 (31.7 $\mathrm{Mg} \mathrm{ha}^{-1}$ ) compared to REF (17.7 Mg ha $\left.{ }^{-1}\right)$. The autumn DMY of REF during the years 2016 and 2017 (1.22 and $8.57 \mathrm{Mg} \mathrm{ha}^{-1}$, respectively) were in line with findings by Clifton-Brown et al. (2001) [54], who reported average DMYs of 1.9 and $6.2 \mathrm{Mg} \mathrm{ha}^{-1}$ for the first two years of cultivation in Germany. This indicates that both the planting procedure and the climatic conditions have met the basic requirements of miscanthus for a good establishment. Thus, any miscanthus yield depression in MUM could be linked to the presence of maize in the year of establishment. It needs to be highlighted that 2018 was a rather dry year indicated by drought events in spring and in summer. Following Ramirez-Almeyda et al. (2017) [13], the overall precipitation of 510.5 mm during January to mid-October was almost unsuitable for miscanthus cultivation. This might have negatively affected the miscanthus yield in both REF and MUM. Due to the higher shoot number in REF than in MUM, the effect of the drought conditions might be stronger in REF than MUM. Furthermore, 
it needs to be highlighted that due to the low planting density of only 1.1 plants $\mathrm{m}^{-2}$ the maximum yield in REF is expected to be reached in year 4 or 5 .

In 2016, miscanthus competed with maize for light and water, which led to a slower miscanthus development followed by a lower miscanthus yield in MUM than in REF. The slow miscanthus development can be explained through (i) a delayed emergence of miscanthus in MUM compared to REF in spring 2017 (Figure 6a,b), and (ii) a lower shoot density than expected [55]. Similar negative effects of unfavorable establishment conditions for miscanthus have been discussed in context of adequate planting date determination, whereas the occurrence of late spring frosts need careful consideration [56]. In our study however, no late spring frosts occurred after the establishment of miscanthus in 2016. Therefore, the delayed emergence of miscanthus in MUM in spring 2017 can only be traced back to the competitive presence of maize during 2016. Furthermore, a significantly lower shoot number was measured in MUM compared to REF in 2016 and 2017 (Figure 7). Even in 2018 (the third growing season), REF had higher shoot numbers than MUM, which shows that the competition of maize in the first year still negatively affected miscanthus growth. The lower shoot numbers have very likely led to the higher weed pressure in MUM compared to REF (Table A1) indicating that MUM requires an intensified weed management in the second and third year. Generally, a higher demand for weed control contradicts to the environmental benefits of miscanthus cultivation, because solely established miscanthus requires no weed control from the second year onwards given a successful weed management in the first year [57]. In this case however, it needs to be considered that MUM required less intense weed control than REF during the year of establishment. This is because miscanthus and maize allow the use of the same herbicides in the first year. Following from this, an additional weed control in MUM in the second year must not automatically contradict the overall environmental benefits of miscanthus cultivation. However, this aspect strongly depends on the local conditions (yield level, weed pressure, etc.) and requires site-/year-specific evaluation.

As shown by Iqbal et al. (2015) [4], miscanthus stands need 3-5 years until they are fully established, i.e., to reach their peak yield. In 2018, the DMY level of REF was within the range of 3rd-year DMYs of miscanthus reported by Lesur-Dumoulin et al. (2016) [58]. In our study however, the DMYs were somewhat stagnating in 2018 (Figure 4) due to low precipitation during April, July and August 2018 (Figure 1). This presumption is based on the fact that sufficient water supply during the vegetation period is generally relevant for both quantity and quality of miscanthus biomass $[3,58,59]$. At first glance, it was surprising to find no significant differences in DMY between MUM and REF given the challenging (water-limited) growth conditions in 2018. One explanation could be that the better-established REF crop with a higher shoot number also had a higher transpiration and was using up the available soil water earlier than the weaker established MUM in 2018. This allowed the MUM crop to catch up in 2018, while the REF crop even showed a yield decline due to drought stress in 2018 compared to 2017. From this we conclude, that REF had a larger physiological DMY gap than MUM in 2018, because the physiological DMY potential of REF was higher than that of MUM. The higher yield potential was explained by the higher number of shoots of REF than those of MUM (Figure $6 c, d$ and Figure 7). Nevertheless, the results of this study showed no significant difference in DMY between MUM and REF in the third year of cultivation. This indicates that the yields of both treatments (MUM and REF) will adapt over time. A similar effect was found for the establishment of perennial wild plant mixtures (WPM) under maize: Both annual and biennial wild plant species showed weakened growth under maize during the first two years of cultivation compared to solely established WPM, whereas the perennial species were able to establish well and generate high biomass yields from the third year onwards [42,43]. Therefore, we propose to further investigate the long-term development of miscanthus established under maize in large-scale field trials in the future.

Based on the above discussion, it can be summarized that a successful establishment of miscanthus under maize is possible. As illustrated in Figure 5, the accumulated three-year DMY of MUM is much higher than REF. This makes the intercropping establishment MUM more profitable than REF, in particular due to the avoidance of a missing yield in the first year of establishment. Consequently, 
MUM combines advantages of both maize and miscanthus: high yields of maize [41] and ecosystem services of miscanthus [17,60-62] from the second year onwards. Farmers could generate a notable income to compensate at least some of the high establishment costs arising in the establishment year [30]. As the missing yield in the initial year is one reason for the low cultivation area of miscanthus [29], the establishment of miscanthus under maize could help to facilitate the implementation of miscanthus cultivation into practices.

Additionally, the establishment of miscanthus under maize promises a crucial environmental benefit compared to sole establishment of miscanthus. In fact, miscanthus is not able to use all the available nutrients, if it is fertilized in the establishment year [9]. However, if miscanthus is established under maize, the nutrient leaching potential of both crops is expected to be lower compared to a subsequent cultivation of miscanthus and maize. This deserves a closer look in future investigations, because a lower $\mathrm{N}$ leaching potential would be in line with the overall perception of a more environmentally benign bioeconomy to keep both resource inputs and negative externalities as low as possible $[6,63]$.

\subsection{Recommendations for Agricultural Practice and Further Research}

The accumulated miscanthus yields (2016-2018) of both establishment varieties were compared and miscanthus in MUM yielded 7.6 $\mathrm{Mg} \mathrm{DM} \mathrm{ha}^{-1}$ lower than in REF (Figure 5). Therefore, several potential key measures for improving the establishment procedure of miscanthus under maize will be discussed in this sub-section. Where possible, recommendations for future investigations will be derived aiming at a faster implementation of miscanthus cultivation into practice.

\subsubsection{Sowing Density of Maize}

The sowing density of maize is seen as major determinant for a successful establishment of miscanthus. Due to low competitiveness of miscanthus during the first two years after establishment [36], a reduction in maize sowing density to 5 kernels $\mathrm{m}^{-2}$ could likely help to reduce the light and water deficits of miscanthus and allow an improved miscanthus establishment in the first year. Similar results were reported for both intercropping maize with common bean (Phaseolus vulgaris L.) $[38,64,65]$ and the successful establishment of cup plant (Silphium perfoliatum L.) under maize [66]. We assume that a reduced maize sowing density could improve the establishment success of miscanthus in terms of both biomass yields and weed pressure from the second year onwards. However, this probably would go ahead with a yield reduction of maize. Therefore, the optimal sowing density of maize must be further investigated.

\subsubsection{Planting Geometry}

The low planting density of miscanthus ( 1.1 plants $\mathrm{m}^{-2}$ ) and the row distance of $0.75 \mathrm{~m}$ resulted in a rather large intra-row distance of $1.2 \mathrm{~m}$. An increased planting density (e.g., 1.66 plants $\mathrm{m}^{-2}$ ) would reduce the intra-row distance to $80 \mathrm{~cm}$ and could improve the performance of miscanthus, especially in the second year and onwards. This could potentially lead to a better weed suppression in the second year of cultivation followed by a higher DMY compared to MUM presented in this study.

\subsubsection{Planting Material of Miscanthus}

In this study, miscanthus plantlets were planted by hand after maize was sown between the maize rows. In practice, rhizome planting is state of the art and would need to be performed for MUM as well. For this reason, miscanthus rhizome planting needs to be performed prior to maize sowing. This is because rhizome planting requires intensive soil disturbance and earlier planting date. After rhizome planting, maize sowing should ideally be conducted using precision farming technology. However, more research is required to identify the ideal maize sowing date and to identify whether a delayed maize sowing could benefit the miscanthus establishment. 


\subsubsection{Risk of Winter Frosts and Plant Losses}

Competition in the first year followed by a poor establishment can increase the risk of plant losses caused by winter frosts. For this reason, the main research target of optimizing this system needs to focus on improving miscanthus growth in the first year (e.g., lower maize planting density, later maize sowing date) and to find a balance between sufficient miscanthus establishment and maize yield. Further research is required for the proposed establishment system to identify the risk of plant losses during winter at different locations, especially for locations with more continental climate, e.g., regular winter frosts. Strategies to reduce the risk of overwinter plant losses could also include breeding and selection of varieties with a higher frost tolerance.

\subsubsection{Harvest Determination}

The harvest date determination is mostly linked to the nurse crop sown with miscanthus. In our study, maize has been chosen as nurse crop and harvested as biogas substrate. Due to a similar harvest window of maize and miscanthus, the harvest date determination is simplified in this case. If other crops are considered to be grown together with miscanthus, one selection-criterion should be that they are harvested also in autumn. This allows miscanthus to relocate nutrients back to rhizomes for a resprouting in the following year. Therefore, grain maize could be the better nurse crop than biogas maize because it is harvested later, which enables a longer nutrient relocation period for miscanthus. This could be relevant for triggering an earlier emergence of potentially higher numbers of miscanthus shoots in the second year of cultivation, which have been identified to be the major concerns in the establishment of miscanthus under maize in this study (Figure 7). Further advantages of the use of maize for grain instead for whole crop silage could be (i) a soil cover with organic residues could help reducing the weed pressure in the second year after establishment of miscanthus, and (ii) the harvest of maize grains could reduce compaction stress for miscanthus plantlets than the harvest of whole above ground biomass because of a low harvest intensity, i.e., a lower number of driving lanes and a lower weight being transported across the field.

\section{Conclusions}

The high dry matter yield (DMY) of maize lead to a significantly higher accumulated three-year DMY of miscanthus under maize establishment (MUM) than for the solely established miscanthus (REF). Miscanthus in MUM showed a poor development compared to REF during the first two years, but it tended to catch up from the third year onwards. Furthermore, the yields of miscanthus in MUM observed in the second year (first standalone year of MUM) were higher than those of the REF in the first year. This indicates that MUM could perhaps enable miscanthus cultivation without unproductive years. However, we suppose that a better adaptation of both maize planting density and miscanthus planting geometry is required to improve the growth conditions for miscanthus in MUM in the year of establishment. Once optimized, we assume that the establishment of miscanthus plantlets under maize could help accelerating the implementation of miscanthus cultivation in Europe and thus, forming a more solid base for an environmentally benign bioeconomy in the long term.

Author Contributions: Conceptualization, M.C., A.M., J.H., I.L. and A.K.; Data curation, M.C. and J.H.; Formal analysis, M.C. and J.H.; Funding acquisition, I.L. and A.K.; Investigation, M.C., A.M. and A.K.; Methodology, M.C., A.M., J.H. and A.K.; Project administration, M.C., Y.I., I.L. and A.K.; Resources, M.C. and A.M.; Software, J.H.; Supervision, I.L. and A.K.; Validation, M.C. and J.H.; Visualization, M.C. and A.M.; Writing-original draft, M.C., A.M., Y.I., J.H., I.L. and A.K.; Writing-review \& editing, M.C.

Funding: This research received funding from the European Union's Horizon 2020 research and innovation programme under grant agreement No 727698, and the German Federal Ministry of Education and Research (BMBF), project number: 03EK3525A. The article processing charge was funded by the European Union's Horizon 2020 research and innovation programme under grant agreement No 727698.

Acknowledgments: The authors are thankful to the staff of the Agricultural Experiment Station of the University of Hohenheim for providing technical support for the field trials, and to Thomas Ruopp, Dr. Moritz Wagner, 
Johanna Class and Walter Schneider for their assistance with field, laboratory and preparatory work. The maize cultivar 'Mikado' (Zea mays L. cv Mikado) was kindly provided by KWS Saat SE (Einbeck, Germany).

Conflicts of Interest: The authors declare no conflict of interest. The funders had no role in the design of the study; in the collection, analyses, or interpretation of data; in the writing of the manuscript, or in the decision to publish the results.

\section{Appendix A}

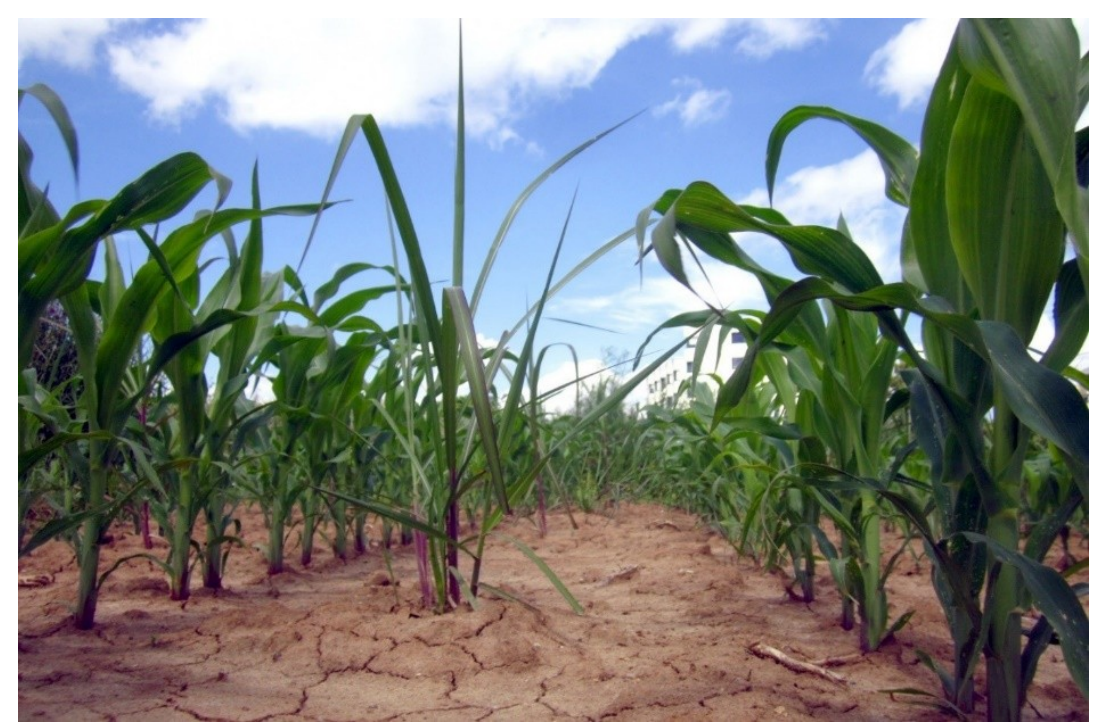

Figure A1. Impression of miscanthus intercropping with maize (MUM), end of June 2016.

Table A1. Dry matter yields (DMY) of weed species at harvest in October 2018.

\begin{tabular}{ccc}
\hline & \multicolumn{2}{c}{ DMY (kg ha $\mathbf{~} \mathbf{~})$} \\
\cline { 2 - 3 } Species & MUM & REF \\
\hline Tanacetum vulgare L. & 305 & 0 \\
Centaurea nigra L. & 50 & 0 \\
Artemisia vulgaris L. & 36 & 70 \\
Cirsium arvense L. Scop. & 20 & 22 \\
Dipsacus fullonum L. & 77 & 0 \\
Melilotus officinalis L. Pall. & 33 & 0 \\
Epilobium L. & 27 & 0 \\
\hline Total & 549 & 92 \\
\hline
\end{tabular}

\section{References}

1. Anderson, E.; Arundale, R.; Maughan, M.; Oladeinde, A.; Wycislo, A.; Voigt, T. Growth and agronomy of Miscanthus $\times$ giganteus for biomass production. Biofuels 2011, 2, 71-87. [CrossRef]

2. Clifton-Brown, J.C.; Lewandowski, I. Water Use Efficiency and Biomass Partitioning of Three Different Miscanthus Genotypes with Limited and Unlimited Water Supply. Ann. Bot. 2000, 86, 191-200. [CrossRef]

3. Heaton, E. A quantitative review comparing the yields of two candidate $\mathrm{C} 4$ perennial biomass crops in relation to nitrogen, temperature and water. Biomass Bioenerg. 2004, 27, 21-30. [CrossRef]

4. Iqbal, Y.; Gauder, M.; Claupein, W.; Graeff-Hönninger, S.; Lewandowski, I. Yield and quality development comparison between miscanthus and switchgrass over a period of 10 years. Energy 2015, 89, 268-276. [CrossRef]

5. Zegada-Lizarazu, W.; Elbersen, H.W.; Cosentino, S.L.; Zatta, A.; Alexopoulou, E.; Monti, A. Agronomic aspects of future energy crops in Europe. Biofuels, Bioprod. Bior. 2010, 4, 674-691. [CrossRef] 
6. Cosentino, S.L.; Scordia, D.; Testa, G.; Monti, A.; Alexopoulou, E.; Christou, M. The Importance of Perennial Grasses as a Feedstock for Bioenergy and Bioproducts. In Perennial Grasses for Bioenergy and Bioproducts; Elsevier: Amsterdam, The Netherlands, 2018; pp. 1-33.

7. Heaton, E.A.; Dohleman, F.G.; Long, S.P. Meeting US biofuel goals with less land: the potential of Miscanthus. Chang. Boil. 2008, 14, 2000-2014. [CrossRef]

8. Lewandowski, I.; Schmidt, U. Nitrogen, energy and land use efficiencies of miscanthus, reed canary grass and triticale as determined by the boundary line approach. Agric. Ecosyst. 2006, 112, 335-346. [CrossRef]

9. McCalmont, J.P.; Hastings, A.; McNamara, N.P.; Richter, G.M.; Robson, P.; Donnison, I.S.; Clifton-Brown, J. Environmental costs and benefits of growing Miscanthus for bioenergy in the UK. GCB Bioenerg. 2017, 9, 489-507. [CrossRef] [PubMed]

10. Cosentino, S.L.; Copani, V.; Scalici, G.; Scordia, D.; Testa, G. Soil erosion mitigation by perennial species under mediterranean environment. Bioenerg. Res. 2015, 8, 1538-1547. [CrossRef]

11. Galatsidas, S.; Gounaris, N.; Vlachaki, D.; Dimitriadis, E.; Kiourtsis, F.; Keramitzis, D.; Gerwin, W.; Repmann, F.; Rettenmaier, N.; Reinhardt, G. Revealing Bioenergy Potentials: Mapping Marginal Lands in Europe-The SEEMLA Approach. In European Biomass Conference and Exhibition Proceedings; Copenhagen, Denmark, 2018; pp. 31-37.

12. Krasuska, E.; Cadórniga, C.; Tenorio, J.L.; Testa, G.; Scordia, D. Potential land availability for energy crops production in Europe. Biofuels Bioprod. Bior. 2010, 4, 658-673. [CrossRef]

13. Ramirez-Almeyda, J.; Elbersen, B.; Monti, A.; Staritsky, I.; Panoutsou, C.; Alexopoulou, E.; Schrijver, R.; Elbersen, W. Assessing the Potentials for Nonfood Crops. In Modeling and Optimization of Biomass Supply Chains, Calliope, P., Ed.; 1st ed.; Elsevier: Amsterdam, The Netherlands, 2017; pp. 219-251.

14. Tuck, G.; Glendining, M.J.; Smith, P.; House, J.I.; Wattenbach, M. The potential distribution of bioenergy crops in Europe under present and future climate. Biomass Bioenerg. 2006, 30, 183-197. [CrossRef]

15. Von Cossel, M.; Iqbal, Y.; Scordia, D.; Cosentino, S.L.; Elbersen, B.; Staritsky, I.; Van Eupen, M.; Mantel, S.; Prysiazhniuk, O.; Maliarenko, O.; Lewandowski, I. Low-input agricultural practices for industrial crops on marginal land (D4.1). In MAGIC Project Report; Supported by the EU's Horizon 2020 programme under GA No. 727698; University of Hohenheim: Stuttgart, Germany, 2018.

16. Clifton-Brown, J.; Hastings, A.; Mos, M.; McCalmont, J.P.; Ashman, C.; Awty-Carroll, D.; Cerazy, J.; Chiang, Y.-C.; Cosentino, S.; Cracroft-Eley, W.; et al. Progress in upscaling Miscanthus biomass production for the European bio-economy with seed-based hybrids. GCB Bioenerg. 2017, 9, 6-17. [CrossRef]

17. Ruf, T.; Makselon, J.; Udelhoven, T.; Emmerling, C.; Ruf, T.; Udelhoven, T. Soil quality indicator response to land-use change from annual to perennial bioenergy cropping systems in Germany. GCB Bioenerg. 2018, 10, 444-459. [CrossRef]

18. Wagner, M.; Mangold, A.; Lask, J.; Petig, E.; Kiesel, A.; Lewandowski, I. Economic and environmental performance of miscanthus cultivated on marginal land for biogas production. GCB Bioenerg. 2018, 11, 34-49. [CrossRef]

19. Iqbal, Y.; Lewandowski, I. Biomass composition and ash melting behaviour of selected miscanthus genotypes in Southern Germany. Fuel 2016, 180, 606-612. [CrossRef]

20. Mangold, A.; Lewandowski, I.; Hartung, J.; Kiesel, A. Miscanthus for biogas production: Influence of harvest date and ensiling on digestibility and methane hectare yield. GCB Bioenerg. 2018, 11, 50-62. [CrossRef]

21. Van der Weijde, T.; Kiesel, A.; Iqbal, Y.; Muylle, H.; Dolstra, O.; Visser, R.G.F.; Lewandowski, I.; Trindade, L.M. Evaluation of Miscanthus sinensis biomass quality as feedstock for conversion into different bioenergy products. GCB Bioenerg. 2017, 9, 176-190. [CrossRef]

22. Iqbal, Y.; Lewandowski, I. Inter-annual variation in biomass combustion quality traits over five years in fifteen Miscanthus genotypes in south Germany. Fuel Process. Technol. 2014, 121, 47-55. [CrossRef]

23. Kiesel, A.; Lewandowski, I. Miscanthus as biogas substrate - cutting tolerance and potential for anaerobic digestion. GCB Bioenerg. 2017, 9, 153-167. [CrossRef]

24. Von Cossel, M.; Möhring, J.; Kiesel, A.; Lewandowski, I. Optimization of specific methane yield prediction models for biogas crops based on lignocellulosic components using non-linear and crop-specific configurations. Ind. Crops Prod. 2018, 120, 330-342. [CrossRef] 
25. Lewandowski, I.; Clifton-Brown, J.; Trindade, L.M.; Linden, V.D.; Schwarz, K.-U.; Müller-Sämann, K.; Anisimov, A.; Chen, C.-L.; Dolstra, O.; Donnison, I.S.; et al. Progress on Optimizing Miscanthus Biomass Production for the European Bioeconomy: Results of the EU FP7 Project OPTIMISC. Front. Plant Sci. 2016, 7, 1620. [CrossRef]

26. Atkinson, C. Establishing perennial grass energy crops in the UK: A review of current propagation options for Miscanthus. Biomass Bioenerg. 2009, 33, 752-759. [CrossRef]

27. Bocquého, G.; Jacquet, F. The adoption of switchgrass and miscanthus by farmers: Impact of liquidity constraints and risk preferences. Energy Policy 2010, 38, 2598-2607. [CrossRef]

28. Olave, R.; Forbes, E.; Munoz, F.; Laidlaw, A.; Easson, D.; Watson, S. Performance of Miscanthus $\times$ giganteus (Greef et Deu) established with plastic mulch and grown from a range of rhizomes sizes and densities in a cool temperate climate. Field Crops Res. 2017, 210, 81-90. [CrossRef]

29. Witzel, C.-P.; Finger, R. Economic evaluation of Miscanthus production-A review. Renew. Sustain. Energy Rev. 2016, 53, 681-696. [CrossRef]

30. Xue, S.; Kalinina, O.; Lewandowski, I. Present and future options for Miscanthus propagation and establishment. Renew. Sustain. Energy Rev. 2015, 49, 1233-1246. [CrossRef]

31. Ashman, C.; Mos, M.; Robson, P.; Awty-Carroll, D.; Clifton-Brown, J.; Awty-Carroll, D.; Clifton-Brown, J. Assessing seed priming, sowing date, and mulch film to improve the germination and survival of direct-sown Miscanthus sinensis in the United Kingdom. GCB Bioenerg. 2018, 10, 612-627. [CrossRef] [PubMed]

32. Zub, H.W.; Brancourt-Hulmel, M. Agronomic and physiological performances of different species of Miscanthus, a major energy crop. A review. Agron. Sustain. Dev. 2010, 30, 201-214. [CrossRef]

33. Soldatos, P. Economic Aspects of Bioenergy Production from Perennial Grasses in Marginal Lands of South Europe. Bioenerg. Res. 2015, 8, 1562-1573. [CrossRef]

34. Rickenbach, O.; Grüebler, M.U.; Schaub, M.; Koller, A.; Naef-Daenzer, B.; Schifferli, L.; Naef-Daenzer, B. Exclusion of ground predators improves Northern Lapwing Vanellus vanellus chick survival. Ibis 2011, 153, 531-542. [CrossRef]

35. Xue, S.; Lewandowski, I.; Kalinina, O. Miscanthus establishment and management on permanent grassland in southwest Germany. Ind. Crop. Prod. 2017, 108, 572-582. [CrossRef]

36. Maksimović, J.; Pivić, R.; Stanojković-Sebić, A.; Vučić-Kišgeci, M.; Kresović, B.; Dinić, Z.; Glamočlija, Đ. Planting density impact on weed infestation and the yield of Miscanthus grown on two soil types. Plant Soil Environ. 2016, 62, 384-388. [CrossRef]

37. Javanmard, A.; Nasab, A.D.M.; Javanshir, A.; Moghaddam, M.; Janmohammadi, H. Forage yield and quality in intercropping of maize with different legumes as double-cropped. J. Food, Agric. Environ. 2009, 7, 163-166.

38. Nurk, L.; Graß, R.; Hubert, S.; Pekrun, C.; Wachendorf, M. Mischanbau von Silomais mit Stangenbohnen. Beiträge zur 13. Wissenschaftstagung Ökologischer Landbau; Verlag Dr. Köster: Berlin, Germany, 2015. Available online: http://orgprints.org/26888/ (accessed on 8 May 2019).

39. Pekrun, C.; Hubert, S.; Zimmermann, C.; Schmidt, W. Gemengeanbau von Mais mit Stangenbohnen - Erste Ergebnisse aus Feldversuchen 2011. In Mitteilungen der Gesellschaft der Pflanzenbauwissenschaften; Verlag Liddy Halm: Göttingen, Germany, 2012; Volume 24, pp. 333-334. Available online: https://www.gpw.unikiel.de/de/jahrestagung/tagungsbaende/tagungsband_2012.pdf (accessed on 8 May 2019).

40. Schmidt, W. Erhöhung der Diversität im Energiepflanzenanbau am Beispiel Mais-Bohnen-Gemenge; Gülzower Fachgespräche: Berlin, Germany, 2013; Volume 45, pp. 77-104. Available online: http://mediathek.fnr.de/ media/downloadable/files/samples/g/f/gfg_band_45_4_symposium_energiepflanzen_final_1.pdf (accessed on 8 May 2019).

41. Von Cossel, M.; Möhring, J.; Kiesel, A.; Lewandowski, I. Methane yield performance of amaranth (Amaranthus hypochondriacus L.) and its suitability for legume intercropping in comparison to maize (Zea mays L.). Ind. Crop. Prod. 2017, 103, 107-121. [CrossRef]

42. Von Cossel, M. Agricultural diversification of biogas crop cultivation. Dissertation. University of Hohenheim, Institute of Crop Science, Stuttgart, Germany. 2019. Available online: https://www.researchgate.net/ publication/332495403_Agricultural_diversification_of_biogas_crop_cultivation (accessed on 8 May 2019). 
43. Von Cossel, M.; Steberl, K.; Möhring, J.; Kiesel, A.; Lewandowski, I. Etablierungsverfahren mehrjähriger Biogas-Wildpflanzenmischungen im Vergleich: Ohne Mais geht's nicht? In Mitteilungen der Gesellschaft der Pflanzenbauwissenschaften; Verlag Liddy Halm: Göttingen, Germany, 2017; Volume 29, pp. 58-59. Available online: https://www.researchgate.net/publication/325477300_Etablierungsverfahren_mehrjahriger_BiogasWildpflanzenmischungen_im_Vergleich_Ohne_Mais_geht $\backslash$ T1 \textquoterights_nicht_In_German (accessed on 8 May 2019).

44. Von Cossel, M.; Lewandowski, I. Perennial wild plant mixtures for biomass production: Impact of species composition dynamics on yield performance over a five-year cultivation period in southwest Germany. Eur. J. Agron. 2016, 79, 74-89. [CrossRef]

45. Von Cossel, M.; Steberl, K.; Hartung, J.; Agra Pereira, L.; Kiesel, A.; Lewandowski, I. Methane yield potential and species diversity dynamics of perennial wild plant mixtures established under maize (Zea mays L.) - A five-year field trial in southwest Germany. GCB Bioenerg.. Submitted for publication.

46. Weiland, P. Biogas production: Current state and perspectives. Appl. Microbiol. Biot. 2010, 85, 849-860. [CrossRef]

47. Maucieri, C.; Camarotto, C.; Florio, G.; Albergo, R.; Ambrico, A.; Trupo, M.; Borin, M. Bioethanol and biomethane potential production of thirteen pluri-annual herbaceous species. Ind. Crop. Prod. 2019, 129, 694-701. [CrossRef]

48. Schmidt, A.; Lemaigre, S.; Delfosse, P.; Von Francken-Welz, H.; Emmerling, C. Biochemical methane potential (BMP) of six perennial energy crops cultivated at three different locations in W-Germany. Convers. Biorefinery 2018, 8, 873-888. [CrossRef]

49. Wahid, R.; Nielsen, S.F.; Hernandez, V.M.; Ward, A.J.; Gislum, R.; Jørgensen, U.; Møller, H.B. Methane production potential from Miscanthus sp.: Effect of harvesting time, genotypes and plant fractions. Biosyst. Eng. 2015, 133, 71-80. [CrossRef]

50. Wolfinger, R. Covariance structure selection in general mixed models. Commun. Stat.—Simul. Comput. 1993, 22, 1079-1106. [CrossRef]

51. Piepho, H.-P. An Algorithm for a Letter-Based Representation of All-Pairwise Comparisons. J. Comput. Graph. Stat. 2004, 13, 456-466. [CrossRef]

52. Kenward, M.G.; Roger, J.H. Small Sample Inference for Fixed Effects from Restricted Maximum Likelihood. Biom 1997, 53, 983. [CrossRef]

53. Kiesel, A.; Wagner, M.; Lewandowski, I. Environmental performance of miscanthus, switchgrass and maize: Can C4 perennials increase the sustainability of biogas production? Sustain. 2017, 9, 5. [CrossRef]

54. Clifton-Brown, J.C.; Lewandowski, I.; Andersson, B.; Basch, G.; Christian, D.G.; Kjeldsen, J.B.; Jørgensen, U.; Mortensen, J.V.; Riche, A.B.; Schwarz, K.-U. Performance of 15 Miscanthus genotypes at five sites in Europe. Agron. J. 2001, 93, 1013-1019. [CrossRef]

55. Bullard, M.J.; Heath, M.C.; Nixon, P.M.I. Shoot growth, radiation interception and dry matter production and partitioning during the establishment phase of Miscanthus sinensis 'Giganteus' grown at two densities in the UK. Ann. Appl. Boil. 1995, 126, 365-378. [CrossRef]

56. Christian, D.G.; Haase, E. Agronomy of miscanthus. In Miscanthus: For Energy and Fibre; James \& James Ltd.: London, UK, 2001; pp. 21-45.

57. Lewandowski, I.; Clifton-Brown, J.; Scurlock, J.; Huisman, W. Miscanthus: European experience with a novel energy crop. Biomass Bioenerg. 2000, 19, 209-227. [CrossRef]

58. Lesur-Dumoulin, C.; Lorin, M.; Bazot, M.; Jeuffroy, M.-H.; Loyce, C. Analysis of young Miscanthus $\times$ giganteus yield variability: a survey of farmers' fields in east central France. GCB Bioenerg. 2016, 8, 122-135. [CrossRef]

59. Schmidt, A.; Lemaigre, S.; Ruf, T.; Delfosse, P.; Emmerling, C. Miscanthus as biogas feedstock: influence of harvest time and stand age on the biochemical methane potential (BMP) of two different growing seasons. Biomass Convers. Bior. 2018, 8, 245-254. [CrossRef]

60. Emmerling, C. Impact of land-use change towards perennial energy crops on earthworm population. Appl. Soil Ecol. 2014, 84, 12-15. [CrossRef]

61. Emmerling, C.; Schmidt, A.; Ruf, T.; Von Francken-Welz, H.; Thielen, S. Impact of newly introduced perennial bioenergy crops on soil quality parameters at three different locations in W-Germany. J. Plant Nutr. Soil Sci. 2017, 180, 759-767. [CrossRef] 
62. Hudiburg, T.W.; Davis, S.C.; Parton, W.; Delucia, E.H. Bioenergy crop greenhouse gas mitigation potential under a range of management practices. GCB Bioenerg. 2015, 7, 366-374. [CrossRef]

63. Scarlat, N.; Dallemand, J.-F.; Monforti-Ferrario, F.; Nita, V. The role of biomass and bioenergy in a future bioeconomy: Policies and facts. Environ. Dev. 2015, 15, 3-34. [CrossRef]

64. I Dawo, M.; Wilkinson, J.M.; Sanders, F.E.; Pilbeam, D.J. The yield and quality of fresh and ensiled plant material from intercropped maize (Zea mays) and beans (Phaseolus vulgaris). J. Sci. Food Agric. 2007, 87, 1391-1399. [CrossRef]

65. Fischer, J.; Böhm, H. Ertragsleistung und Silagequalität von Mais im Mischfruchtanbau mit Bohnen. In Mitteilungen der Gesellschaft der Pflanzenbauwissenschaften; Verlag Liddy Halm: Göttingen, Germany, 2012; Volume 24, pp. 325-326. Available online: https:/www.researchgate.net/publication/289125401_Ertragsleistung_und_ Silagequalitat_von_Mais_im_Mischfruchtanbau_mit_Bohnen (accessed on 8 May 2019).

66. Stolzenburg, K.; Bruns, H.; Monkos, A.; Ott, J.; Schickler, J. Produktion von Kosubstraten für die Biogasanlage-Ergebnisse der Versuche mit Durchwachsener Silphie (Silphium perfoliatum L.) in Baden-Württemberg. In Informationen für die Pflanzenproduktion; Landwirtschaftliches Technologiezentrum Augustenberg: Karlsruhe, Germany, 2016; Available online: http: //www.ltz-bw.de/pb/site/pbs-bw-new/get/documents/MLR.LEL/PB5Documents/ltz_ka/Service/ Schriftenreihen/Informationen\%20f\%C3\%BCr\%20die\%20Pflanzenproduktion/IfPP_2016-04_Silphie/ IFPP\%2004-2016\%20Durchwachsene\%20Silphie.pdf?attachment=true. (accessed on 8 May 2019).

(C) 2019 by the authors. Licensee MDPI, Basel, Switzerland. This article is an open access article distributed under the terms and conditions of the Creative Commons Attribution (CC BY) license (http://creativecommons.org/licenses/by/4.0/). 